\title{
Analysis of problems and policy suggestions in the construction of business environment in China
}

\author{
Yonghui $\mathrm{CAO}^{1, \text { a }}$, He JIANG ${ }^{1 *}$ \\ ${ }^{1}$ Department of Business Administration, Guangzhou College of Technology and Business, Guangzhou, China
}

\begin{abstract}
Building a good business environment is of positive significance for the healthy growth of enterprises and the high-quality development of China's economy. China has achieved positive results in recent years, but there are still problems in some aspects, which has become an obstacle to the further development of China's economy. Therefore, based on the actual situation of our state-owned business environment, this paper focuses on the core problems, analyzes the causes and puts forward relevant policy recommendations. This paper mainly analyzes the construction of government environment, business law environment and the internationalization of business environment, so as to provide reference and reference for the high quality of China's economy.
\end{abstract}

\section{INTRODUCTION}

By creating a good business environment, enterprises can reduce the burden in the process of business, promote social employment and stabilize economic development[1,2]. It has been proved that a transparent and efficient business environment strengthens the protection of entrepreneurs' property rights, can boost the confidence of foreign-funded enterprises in China's investment, has a positive role in promoting the development of China's foreign trade, and has an important impact on the expectation of stable economic development $[3,4]$. At the same time, optimizing the business environment in the new era is the need to speed up the construction of a modern economic system and promote high-quality development[5,6]. China has made outstanding achievements in optimizing the business environment, but there is still a big gap from the requirements of the socialist modernization power. Based on the practical and theoretical background, through indepth thinking and combing of the research problems, the basic problems of this paper are summarized: how to analyze the problems and make policies for the development of the state-owned business environment? Next, the problem will be systematically and in-depth studied $[7,8,9]$.

Here is a comparison between China and New Zealand (ranking first in the world in business environment), We can see that there is still a big gap between China and the advanced countries in the world.

Figure 1 Comparison between China and New Zealand

\begin{tabular}{ccccc}
\hline country & \multicolumn{2}{c}{ New Zealand } & \multicolumn{2}{c}{ China } \\
$\begin{array}{c}\text { Year } \\
\text { Rank and Score }\end{array}$ & $\begin{array}{c}\text { DB2020 } \\
\text { ranking }\end{array}$ & $\begin{array}{c}\text { DB2020 } \\
\text { Score }\end{array}$ & $\begin{array}{c}\text { DB2020 } \\
\text { ranking }\end{array}$ & $\begin{array}{c}\text { DB2020 } \\
\text { Score }\end{array}$ \\
\hline total & 1 & 86.8 & 31 & 77.9 \\
\hline $\begin{array}{c}\text { Starting a Business } \\
\begin{array}{c}\text { Dealing with Construction } \\
\text { Permits }\end{array}\end{array}$ & 1 & 100 & 27 & 94.1 \\
\hline $\begin{array}{c}\text { Getting Electricity } \\
\text { Registering Property }\end{array}$ & 48 & 84.0 & 12 & 77.3 \\
\hline Getting Credit & 1 & 94.6 & 28 & 81.0 \\
\hline $\begin{array}{c}\text { Protecting Minority } \\
\text { Investors }\end{array}$ & 3 & 86.0 & 28 & 72.0 \\
\hline Paying Taxes & 9 & 91.0 & 105 & 70.1 \\
\hline Trading across Borders & 63 & 84.6 & 56 & 86.5 \\
\hline Enforcing Contracts & 23 & 71.5 & 5 & 80.9 \\
\hline Resolving Insolvency & 36 & 69.5 & 51 & 62.1 \\
\hline
\end{tabular}

\footnotetext{
* Corresponding author: He JIANG, GZhappy2020@126.com

axinrui20132015@126.com
} 


\section{ANALYSIS OF THE PROBLEMS AND CAUSES IN THE ENVIRONMENTAL CONSTRUCTION OF STATE-OWNED BUSINESS}

\subsection{Lack of Innovation in Government Environment Construction and Imperfect Market Supervision}

(1) The government system reform is not in-depth, and the government reform in some business areas needs to be improved

The effect of business environment construction is closely related to the reform of the government system. By changing the way and process of government affairs, the convenience of business operation can be improved, the internal vitality of the enterprise can be stimulated, and the enterprise can obtain the expected benefit return. In recent years, the reform of deregulation services, to a large extent, is aimed at the system reform of government departments. From the practical effect, the research results show that in some areas, the reform of China's government affairs system has achieved positive results, such as the reduction of the links of starting enterprises, the optimization of time and cost. However, the government reform in some key areas needs to be improved, such as credit, tax, access to electricity and so on. In the process of starting an enterprise, the obtaining of business license is only the "pass" for the entry of the enterprise in some way, while the environment of credit, power, contract execution and so on is the key factor directly related to business activities in the enterprise operation process, which is more important. This is exactly where our government should take the initiative, and it is also a key measure to promote the construction of business environment.

Therefore, in today's urgent need for in-depth reform of the government environment, we need to refine the core areas of government reform, especially for some weak areas of government, we need to increase the reform efforts and solve the existing mechanism obstacles.

(2) The implementation of the reform of "deregulation service" is not in place

In order to optimize the business environment and improve the convenience of business operation, from the central government to the local government, they are carrying out the reform of "deregulation service", especially in the aspect of streamlining administration and delegating power. They have done a lot of work, reduced and compressed many procedures, and improved efficiency. However, in some areas, the local government still adheres to the traditional concept of social governance in terms of streamlining administration and delegating power. It has a resistance to delegating power, and there is a situation of "light and dark", and the business activities of enterprises are often interfered by the government. For example, the process of administrative examination and approval is still complicated, and the cost of administrative services is high, which leads to the fact that enterprises do not feel the convenience brought by the reform of "deregulation service", weakening the credibility of the government. At present, the tide of "mass entrepreneurship and innovation" is surging, and the market is booming. However, our government has limited or no action in adapting to the development of new economy, adheres to the old management concept, has poor service awareness, and does not implement the spirit of deregulation and service reform in place. These problems must be paid attention to and solved as soon as possible.

(3) The efficiency of E-government has not been brought into full play, and there is information island phenomenon

The central government attaches great importance to the construction of e-government information platform, and promotes the "Internet + government services" to the strategic height of the reform of the government system, so as to serve as the key starting point for optimizing the business environment. From the reality of China's reform, the construction of government service platform has a high enthusiasm. From the national level to all departments and regions, corresponding government service platforms have been successively established, which indeed provides greater convenience for enterprises and the masses. However, due to the reform is still in the exploratory period, some government data have not yet been interconnected, and there is the phenomenon of information island, leading to the Limited handling effect of some government affairs, even because of the different statistical caliber of information data, there is a data contradiction phenomenon. The low efficiency of information utilization seriously restricts the improvement of administrative efficiency and naturally leads to the low efficiency of service. Therefore, from the aspect of egovernment reform, we should establish a national, provincial and municipal integrated government platform system as soon as possible, and make the data and information across regions and systems shared, so as to give full play to the efficiency of e-government.

(4) Some industries have high hidden administrative system barriers

The construction of business environment aims to break the shackles and restrictions brought by the external environment and mechanism obstacles, create a good business atmosphere for the market micro main body, and fundamentally improve the business confidence of enterprises, and promote the high-quality development of economy. However, there are still high administrative system barriers in most regions, which affect the transformation and upgrading of enterprises, especially private enterprises. The transition protection policies of state-owned enterprises set up in some industries affect the enthusiasm of private enterprises to actively participate in the construction.

(5) There are drawbacks in government procurement and imperfect market supervision mechanism

The market supervision system of local governments in China is not perfect, and the inspection system for product quality cannot meet the market requirements, which is far from the internal requirements of rapid and high-quality economic development in China. The 
government departments of our country often adopt the product inspection system for the inspection of the product quality of enterprises, and the sampling inspection system is used in a small range. On the one hand, the number of industrial and commercial and quality inspection personnel is relatively limited, which cannot meet the needs of a large number of product sampling. On the other hand, it is also the traditional practice of the government supervision mechanism, which cannot guarantee the objectivity and fairness of product inspection. At present, this kind of market supervision and supervision mechanism of the government cannot form an effective supervision on the relevant enterprises of fake and inferior products, resulting in the circulation market of some low-end and inferior products, which encourages the arrogance of low-quality products and fake and inferior products manufacturers. It is precisely because of the lack of fairness in the supervision of the product quality supervision department that it has become a high incidence area of corruption in China. Some production enterprises with low product quality get special protection from some government officials through rent-seeking, so that the imitated products or inferior products can be sold normally in the market, which makes some excellent enterprises unable to obtain the profits brought by innovation, and affects the innovation enthusiasm of enterprises. Therefore, it is necessary to strengthen the supervision and supervision ability of the government to enter the deep area of business environment reform.

\section{2 the Business Legal Environment is Short, and Relevant Laws and Regulations need to be Improved}

Diversified settlement mechanism of commercial disputes, on the one hand, is an important part of building a legal business environment, on the other hand, is a key measure to build a shared social governance pattern. Because the commercial disputes in the process of business environment reform have the characteristics of multiple subjects and complex patterns, and especially considering the pursuit of efficiency value of commercial disputes, the common litigation mechanism can not meet its growing needs on the one hand, and on the other hand can not properly meet its fair needs for the reasonable settlement of disputes. How to reduce the cost of protecting the rights of commercial subjects through legal channels is a key issue to build a legal business environment.

\subsection{Low Degree of Internationalization of Business Environment, Lack of Business Rules System in Line with International Standards}

China's business environment is changing towards international vision and institutional mechanism innovation, but the degree of internationalization of business environment is relatively low. There is little or no connection with international rules and practices, no relatively perfect international planning and construction system, and no efficient economic operation mode in line with international standards. We are not familiar with or even unfamiliar with the international industry standards. Although China has been reforming and opening up for decades, the open emerging industry system is not sound enough, and the international government operation system is not comprehensive enough. These problems lead to our country often at a disadvantage in the international competition. It is imperative and urgent to establish an international business environment.

\section{POLICY SUGGESTIONS FOR OPTIMIZING BUSINESS ENVIRONMENT}

\subsection{Build a Transparent and Efficient Government Environment and Supervise Market Subjects According to Law}

The reform of the government itself is the main link to optimize the business environment. As the main body of optimizing the business environment, the government should continue to deepen the reform of the administrative examination and approval system, promote the simplification of administration and decentralization of power, take better service for the main body of the market as the goal, improve the level of government services, increase the openness of policies, and build a transparent and efficient government environment, that is to say, build a service-oriented government. Specifically, on the one hand, local governments at all levels innovate in the administrative examination and approval system, greatly simplify the administrative examination and approval matters, simplify the administrative examination and approval procedures, and then shorten the examination and approval time, focusing on making substantive breakthroughs in market access, market supervision, factor allocation and other fields. We need to update the concept of administrative governance, realize the innovation of administrative management and means, and transform the market behavior of the government to the main body of investment and operation from "strict management" to "strict management", from "focusing on examination and approval" to "focusing on service", from being used to direct micro management to indirect management and macro-control,

We should regulate the process of government's supervision over market subjects. Governments at all levels gradually establish and improve the market supervision responsibility system, formulate market supervision rules, procedures and standards, strengthen the supervision of market subject behavior according to law, ensure fair competition among market subjects, and maintain market order. The system of "market random inspection" for product quality evaluation shall be clearly established, and the market subjects shall be supervised according to law. The government strengthens the main responsibility of operators, improves the product quality standards and management system, constructs the whole process traceability system of quality supervision mode with risk monitoring and hazard control as the main content, and implements the integrated supervision of product quality. In view of the current situation that fake 
and substandard products are hard to eliminate in a short time in China's enterprises, governments at all levels and relevant departments should strengthen the implementation of the "product inspection system" and conduct regular spot checks on the designated product areas. In addition, it is also necessary to strengthen the professional team construction of product quality inspection, supervision and illegal enforcement agencies, strengthen the supervision scope and strength of product quality, and severely punish related corruption, so as to ensure the product quality entering the market to the maximum extent.

We will improve the market supervision system and establish a market mechanism for fair competition. Governments at all levels should further strengthen the systematization, legality and enforceability of the market supervision system, form a system of "complete system, scientific norms and effective operation", and ensure that the market supervision and other relevant departments fully perform the supervision functions of the market subjects in accordance with the law. First, we need to gradually change our prior supervision and move the focus of market supervision back. We should reverse the trend of "focusing on examination and approval, ignoring supervision", transform the "main business" from examination and approval to supervision and law enforcement, and shift the "operation focus" from pre control to in process and post control. Second, improve the information sharing system. Open market supervision implementation information, promote the power list system of the government and regulatory authorities, and open the power operation process in accordance with the law. At the same time, the big data system and management mechanism of enterprise information should be built to strengthen the sharing of supervision information and credit information. Third, the government should strengthen the institutional constraints on market supervision and law enforcement. With the development of China's economy, the reform of the market supervision system needs to be speeded up to better serve the economic development, that is, to speed up the full implementation of "two random and one open" in market supervision, improve the level of administrative law enforcement, and maximize the fairness and scientificity of law enforcement. Fourth, to achieve the fairness and convenience of market competition through regulatory system reform. We will gradually break down the industry barriers for private capital to enter the market, so that all enterprises can equally participate in market competition, share public services, and maximize the vitality of economic development.

\subsection{Build a Fair,Jjust and Equal Legal Environment to Provide Legal Guarantee for Business Environment}

A fair, just and equal legal environment is the basis of a good business environment. The report of the 19th National Congress of the Communist Party of China points out that the rule of law is the basic implementation strategy of our country. The comprehensive rule of law is a profound revolution in deepening reform, promoting development, resolving contradictions, maintaining stability and coping with risks by using the thinking and way of rule of law. It is an inevitable requirement for the modernization of national governance system and capacity. In this context, we must carry out the top-level design from the legislative level according to the indicators of business environment. First, optimize the process of obtaining business resources, reduce the cost of obtaining business resources, and establish industry standards that are conducive to improving business environment indicators. Second, according to the concept of "the least link, the simplest procedure, the shortest time, the best service and the highest efficiency", the examination and approval items and processes are sorted out and optimized, and the examination and approval submission materials are simplified to the greatest extent, so as to ensure the examination and approval quality while improving the examination and approval efficiency. The third is to establish the bankruptcy protection system to reduce the economic and social pressure that enterprises should bear when facing risks. Fourth, gradually improve the credit system of our country and improve the credit index of the whole society.

\subsection{Build a Win-win International Environment and Expand Economic and Trade Cooperation with Other Countries}

After China's accession to the WTO, China has shared the dividends of economic globalization by accelerating the process of opening up to the outside world, and has become a world manufacturing and trade and investment power by accelerating its integration into the global industrial chain and value chain system. This requires our country to establish a business rules system that is in line with the international standards as soon as possible, that is, we should take the initiative to connect with the international conventions and rules in the international trade, and introduce the international industry norms and management standards in the daily operation and management of enterprises as the enterprise management norms; In terms of international trade rule making, our government and enterprises should actively strive for the dominant power of rule making; in addition, the government should vigorously support enterprises to actively participate in the formulation of international standards and establish a business rule system that is in line with international standards. With the expansion of China's economic aggregate, we should play a more important role in international organizations in the future. At the same time, we should strengthen dialogue and exchange with other countries in the world, and use WTO rules to safeguard the interests of domestic enterprises. In addition, we will expand economic and trade cooperation with other countries around the world and continue to promote the construction of free trade zones. Through the "one belt and one way" initiative, we will deepen communication and cooperation with all countries along the economic, technological and cultural aspects, open up 
new markets, increase our export volume, and form longterm benign and mutually beneficial cooperation.

\section{CONCLUSION}

In a word, the world is now in an unprecedented great change. Various factors are overlapping, which has brought a lot of uncertain effects on China's economic development. The improvement of export-oriented economy requires China to establish a business environment that adapts to external changes, so as to effectively promote opening up and enhance the ability of local enterprises to participate in international competition. To create a first-class business environment, we need to reflect on ourselves, also need to be familiar with the international operation rules, and promote the system construction and mechanism innovation through our own efforts and openness. For China, to build a first-class business environment, improve the competitiveness of local enterprises, and promote the healthy development of China's economy are the best strategic measures.

\section{ACKNOWLEDGMENT}

This work is financially supported by Guangdong Education Science Planning Project, building an efficient and intelligent supply chain system to promote the highquality economic development of Guangdong-Hong Kong-Macao Greater Bay Area, 2019GXJK072; outstanding scholars of philosophy and Social Sciences in Henan Province higher education in 2018, 2018-YXXZ06; Henan philosophy and Social Sciences Planning Project in 2019, 2019BJJ003; The social development project of Henan provincial key R \& D and promotion project (Science and technology tackling key problems) in 2019, project number: 515; Henan philosophy and Social Sciences Planning Project in 2019, 2019BJJ032; General Topics of Henan Province Educational Science "13th Five-Year Plan" in 2020, 2020YB0146; the key scientific research project of colleges and universities in Henan
Province in 2021, 21A620002; Foshan social science planning project in 2020, 2020-QN11; Intellectual property soft science research project of Henan Province in 2021, 20210106014. Thanks for the help.

\section{REFERENCES}

1. Doing business group of the World Bank. Doing Business 2020. https://chinese.doingbusiness.org/

2. He Lisheng. Improving business environment and building a new open economic system [J]. Research on modern state-owned enterprises, 2018 (9): 16

3. Li Zhijun, Zhang Shiguo, Li Yifei, et al. Evaluation of urban business environment in China and relevant suggestions [J]. Jiangsu Social Sciences, 2019 (2): 5

4. Peng diyun, Chen Bo, Liu Zhijia. Construction and application of regional business environment evaluation index system-Taking Yangtze River economic belt as an example [J]. Finance and economy, 2019, 1 (5): 49-55

5. Siewiorek A, Saarinen E, Lainema T, et al. Learning leadership skills in a simulated business environment[J]. Computers \& Education, 2012, 58(1): 121-135.

6. Vogiatzoglou K. Ease of doing business and FDI inflows in ASEAN[J]. Journal of Southeast Asian Economies, 2016: 343-363.

7. Zhang Wei. Problems in China's state-owned business environment and optimization suggestions [J]. Journal of theory, 2017 (5): 60-72.

8. Newman C, Rand J, Tarp F, et al. Corporate social responsibility in a competitive business environment $[\mathrm{J}]$. The Journal of Development Studies, 2020: 1-18.

9. Samad K A, Mubarak A S. Being Agile In Dynamic Business Environment[J]. Our Heritage, 2020, 68(1): 3778-3783. 